wherever plants get free access to the open air above, it was one of my own assertions that they must necessarily obtain carbonic acid in abundance. It seems to me difficult to understand how in a still place, where many plants at once are engayed in deoxidising a compund which only normally forms $0^{\circ} \mathrm{O} 3$ per cent. of the atmosphere, there can always be as much of it left as any of them can possibly want. I do not presume to argue with Prof. Dyer upon the subject; but as far as my own comprehension goes, he has not made this point clear to me.

May I venture also to suggest that perhaps another danger surrounds biology, arid especially botany-the danger of becoming too technical and too academic? Now that perfect instruments, inmense collections, and a long technical training are neces ary in order to do anything in biology by the regular road, does not the science run just a little risk of falling into a groove? And is it not well from this point of view that there should be an outside body of amateurs, who will take occasionally a fresh non professional view of the subject, handling their own problems in their own way, and publishing their own little guesses or glimpses for what they may be worth? No doubt they will often go demonstrably wrong; no doubt the master of the science will usually find numerous blunders of detail in their work, and may often see reason to di agree with them altogether; and in that case the amateurs ousht to receive their corrections with all humility; but is it not a healthy thing after all that the amateurs should do their best, and try to follow out their own lights to their own conclusions? GRANT ALLEN

\section{Forms of Leaves}

You have recently inserted several letters from Mr. Grant Allen on the forms of leave;, a question in which I have myself been working lately. Mr. Grant Allen's letters open up a number of interesting questions, but for the moment I will only refer to his suggestion with reference to the reason why water plants so often have their leaves cut up into fine filaments. He tells us that this is because the proportion of carbonic acid held in solution by water is very small, and that theref rre for this amount there is a great competition among the various aquatic plants.

The question has already been asked on what grounds $\mathrm{Mr}$. Allen makes this starement with reference to the proportionate amount of carbonic acid. Without entering on this point, I would, however, venture to suggest that the reason for this tendency in the leaves of water plants is mechanical rather than che nical.

It is, of course, important for all leaves to present a large surface for the purposes of ab-orption with as little expenditure of material for purposes of support as possible. Now delicate filaments such as those of water plants present a very large area of surface in prop ortion to their mass. On the other hand, they are unsuited to terrestrial plants, because they are deficient in strength and unable to support themselves in air. Take, for instance, a handful of the submerged leaves of an aquatic ranunculus ont of the water, and, as every one knows, the filaments collapse. This seems to me the real reason why this form of leaves is an advantage to water plants. It is perhaps for the same reason that low-growing herbs, which are thus protected from the wind so often have much divider leaves. April

JOHN LUBBOCK

\section{The Föhn}

MAY I be allowed the space of a few lines to point out a defect in the acc unt of the Föhn, given by Mr. Scott in his recent work on "Meteorology," and quoted in the review of that work which appeared in NATURE, vol. xxvii. p. 575. This phenomenon has been fully and clearly explained by Dr. $\mathrm{J}$. Hann in a paper entitled "Einfährung in die Meteorologie der Alpen," published under the auspices of the D. und O. Alpenverein. Mr. Scott's account of the Föhn attributes rightly the dryness and the cooling of the wind at high altitudes to expansion; but he appears to entirely overlook the heating effect due to condensation of moisture during the ascent of the $\mathrm{u}$ ind.

From observations made in Switzerland, where the Föhn is chiefly felt, Hann has established the following rule: the Föhn is as many half degrees C. warmer at any place in its de-cent, than it is at an equal altitude during its previous ascent on the other side, as the place is hundreds of metres below the mountain ridge. This he explains by the fact that compression during the descent of the Föhn reverses the loss of temperature due to rare- faction during its previcus ascent; while the wind brings with it over the mountain ridge the heat gained by the liberacion of latent beat in the condeusation of moisture. This latter amounts at $15^{\circ} \mathrm{C}$. to about half a degree C. for each ascent of 100 metres for saturated air. "Therein," says Hann, "lies the explanation of the heat of the Föhn."

Welliogton College, Berks, April 21

A. IRVING

\section{The Zodiacal Light (?)}

THE same "peculiar appearance in the western sky" as that described by your correspondent, "I. W. B.," was observed here by me on the same evening, April 6. At 7 h. Om. G.M.T., or fifteen minutes after sunset, I noticed a bright, golden. coloured column of light, well defined, about $4^{\circ}$ in length and slightly more than $I^{\circ}$ in width, and inclined towards the south. "J. W. B." says it "rose vertically from near the horizon" at his station, Bath. Here it was decidedly inclined to an angle of about $15^{\mathrm{c}}$ towards the south. At $7 \mathrm{~h}$. 20m. no traces of it were visible. I have not seen any similar appearance since.

\section{W. H. RoBinson}

N.B. - In the observer's book this observation is entered as "Bright zodiacal light (?), seen at 7h. om."

Radcliffe Observatory, Oxford, April zo

E. J. STONE

REFERRING to the letter of your correspondent, "J. W. B.," Bath, in your last is sue (p. 580), allow me to say that this peculiar ray of brilliant light was seen here by myself and many other people at ahout $6.40 \mathrm{p.m}$. on Friday, A pril 6. The sunset was brilliant and cloudless, but from the horizon to about $25^{\circ}$ in height immediately abuve the spot where the sun had disappeared there appeared a ray of light of great beauty and extreme brilliancy ; it sentre, a delicate rose colour, graduating to the edges into the purest gold. This single ray was perpendicular, and appeared to be little, if at all affected, in its brilliancy by the apuroaching dusk of evening, but continued to exhibit itself with little-diminished brilliancy for nearly half an hour, finally disappearing with the twilight.

Glan-y-dwr, Crickhowell, South Wales, April 21

WHAT your cerrespondent, "J. W. B.," saw after sunset was not the zodiacal light, which is easily distinguishable by its great extent of area, lenticular shape, and invisibility during strong twilight, but it may be not incorrectly termed a sun column. I find the following entry in an old journal, of a similar appearance :-“" 1868 , A pril I 7. - Sun column, continuing balf an hour after sunset, which was perfectly bright, without clouds." Perhaps some of your readers may be able to explain the cause of it.

E. BROWN

Further Barton, Cirencester, April 2I

THE phenomenon observed on the evening of Friday, the 6th inst., in Bath, by your correspondent J. W. B. (vol, xxvii. p. 580) was seen at Dolgelly by the writer when on a tour through Wales. On his pointing it out to a companion and some of the townsfolk, all agreed it was quite unique in their experience.

A bright, slender pillar of light, hazy toward the edyes, rose majestically from the western horizon, in a cloudless sky, and so continued for about three-quarters of an hour after the sun had set. To one ling habituated in meteorological observation it was of a character differing toto colo from the path of sunbeams through a cloud-rift, which is invariably divergent in appearance, as if from a focus. The "pillar" was uniform in width, perfectly vertical, and straight, the centre line alone brilliant. The height was, however, greater than your correspondent indicates.

Having fortunately with me a pocket-compass, with plumbbob for "dip" measurements, I determined (I) the light-pillar was exacly vertical; (2) the height, which scarcely varied during visibility, was $20^{\circ}$, dying out faintly at that elevation; (3) the azimiuth $25^{\circ}$ north of west. By terrestrial bearings there was an appearance or a slight movement northward, but smallness of the compass dial (i inch diameter) precluded any reliable angular determination of azimuthal change.

Further, the evening was very cold, and a continuous easterly wind had during the day obscured the hills, which still showed many unmelted snowdrifts upon their summits and flanks. First observed at $7 \mathrm{p} . \mathrm{m}$., the strange appearance faded out at $7.30 \mathrm{p} . \mathrm{m}$. 